\title{
BJHS special section: book history and the sciences
}

\section{Introduction}

\author{
JONATHAN R. TOPHAM*
}

The expanding interest in book history over recent years has heralded the coming together of an interdisciplinary research community drawing scholars from a variety of literary, historical and cultural studies. Moreover, with a growing body of literature, the field is becoming increasingly visible on a wider scale, not least through the existence of the Society for the History of Authorship, Readership and Publishing (SHARP), with its newly founded journal Book History. Within the history of science, however, there remains not a little scepticism concerning the practical value of such an approach. It is often dismissed as an intellectual fad or as an enterprise which is illuminating but ultimately peripheral, rather than being valued as an approach which can offer major new insights within the field. This is no doubt in part because much of the most innovative work in history of science over recent years has been carried out by historians anxious to get away from an earlier overemphasis on printed sources. Eager to correct a profoundly unsocial history of ideas, usually rooted in texts, historians have looked increasingly to both the practices and the material culture of science. In such a context, a renewed focus on the history of books sometimes seems like a retrograde step, especially given the common misidentification of 'books' with 'texts'. On the contrary, however, it is just such a twin emphasis on practices and material culture which also characterizes the new book history. Indeed, to the question 'what is book history for?' we might answer that its object is to reintroduce social actors, engaged in a variety of practices with respect to material objects, into a history in which books have too often been understood merely as disembodied texts, the meaning of which is defined by singular, uniquely creative authors, and is transparent to readers.

In critical ways book history involves expecting both less and more from the printed objects that survive in our libraries and private collections. On the one hand, it entails further problematizing books as sources of evidence for the beliefs of historical actors. This is perhaps most startlingly so with readers, whose engagement with books had much less to do with the books themselves, and much more to do with the complex of commercial and reading practices in which readers were involved, than we have been wont to suppose. It is also the case with authors, since their involvement in a turbulent world of book

* Science in the Nineteenth-century Periodical (SciPer) Project, School of Philosophy, University of Leeds, Leeds LS2 9JT, and Department of English Literature, University of Sheffield, Shearwood Road, Sheffield S10 2TD. 
manufacture and distribution undermines any naïve notion of the singularity of authorial creativity, revealing instead a complex of authorial and publishing practices in which books appear as the products of divided labour. On the other hand, however, book history demands that we expect much more from our books. Far from being merely texts that can be reproduced by microfilm or facsimile, books are material objects replete with historical evidence. As much as any other historical artefacts, they contain not only physical evidence concerning the processes of their manufacture, but also physical evidence which is essential in constructing a history of their use - from the typography and layout to the paper and the binding. In book history, such evidence is combined with external evidence to elaborate fundamentally social accounts of the fabrication, distribution and use of printed objects.

Book history, therefore, applies to print culture an approach which historians of science have pioneered in other contexts, such as studies of laboratories, observatories, lecturehalls and museums. Moreover, the approach in this case yields similar dividends in providing insights into the craft that is required in the making of natural knowledge. By focusing on the practices of fabrication, distribution and use, book history continually reveals both the instability of meaning in printed objects, and the labour that is consequently expended by those seeking to establish universal claims through printed means. Such insights are of no small significance for the history of science. As Adrian Johns has argued for the early modern period, the success or failure of natural philosophers in establishing their theories as universals depended heavily on their management of a 'seemingly undisciplined print culture'.' Similarly, I have argued that the creation of modern specialized science in the nineteenth century was accomplished in a context in which the stability of meaning in paper and print was constantly undermined, not least by readers active in appropriating or even subverting the science of the gentlemanly specialists. ${ }^{2}$ Repudiating a history of scientific popularization predicated on a diffusionist model, this approach problematizes the mechanics of communication through print, revealing the craft of all those involved in the making of meaning, including readers and publishers as much as authors.

Of course, certain kinds of practice relating to the fabrication, distribution and use of printed objects are relatively familiar to historians of science. Indeed it is arguable, as Nicolaas Rupke contests in his contribution to this issue, that the 'book history' turn in the history of science has merely led to 'a new, precise and programmatic expression' of an interest in issues which have long preoccupied historians. Nevertheless, the systematic nature of the enquiry has significantly widened its scope, and promises radically new insights.

Perhaps the most obvious focus of historical interest has been on the practices of scientific authorship. Particularly valuable, for instance, has been recent work on the diverse rhetorical forms of published writings on scientific subjects. However, other aspects

1 A. Johns, 'History, science, and the history of the book: the making of natural philosophy in early modern Europe', Publishing History (1991), 30, 5-30, 16. See also idem, The Nature of the Book: Print and Knowledge in the Making, Chicago and London, 1998.

2 J. R. Topham, 'Beyond the "common context": the production and reading of the Bridgewater Treatises', Isis (1998), 89, 233-62; and idem, 'Scientific publishing and the readership for science in early nineteenth-century Britain: an historiographical survey and guide to sources', Studies in the History and Philosophy of Science, forthcoming. 
remain relatively unexplored, most notably the extent to which scientific authors have been embedded in the commercial context of the book trade. Yet, following the rapid commercialization of the book trade in the late eighteenth century, scientific authors often wrote at the behest of, and in the form prescribed by, the newly emerging entrepreneurial publishers. Moreover, the most successful authors could expect increasingly lucrative financial rewards for their labour. The consequences of such commercial changes for the practice of authorship were considerable, affecting not only scientific practitioners but also a rapidly expanding body of scientific writers and journalists who were not themselves practitioners. Indeed, as Bernie Lightman has recently argued, this growing band of writers on science were arguably 'more important than the Huxleys and Tyndalls in shaping the understanding of science in the minds of a reading public composed of children, teenagers, women and nonscientific males'. ${ }^{3}$

Leslie Howsam explores this commercial world of book fabrication in her contribution to this issue, arguing that much of the history of authorship lies hidden beneath 'the bland package of the printed and bound book'. In particular, she shows how bibliographical analysis and description can be used to reveal the continuing development by author and publisher of a book that is putatively stable. We should, of course, remember that much scientific publishing has consisted in the reissuing of 'standard' works, in 'scissors-and-paste' journalism, in translation and in other forms of literary appropriation. Such literary labour tends to remain obscured, yet, as Rupke argues, translations and other literary appropriations are never 'autochthonous cultural products'. On the contrary, the processes of reissue, extracting and translation inevitably transform the meaning of the original text, and are themselves forms of authorship.

More systematic study would also pay dividends in regard to the culture and practices of the book trade itself. Clearly of central importance in regard to both the fabrication and the distribution of scientific publications, the book trade needs to be subjected to much greater historical study since all too little is known about the role of many of the leading publishers, printers, booksellers and binders. Adrian Johns has done much to rectify this for the mid-seventeenth-century London trade, and has shown its importance for the history of science more generally. In his essay in this issue, Johns uses his knowledge of the contemporary book trade to turn the eventual success of the Philosophical Transactions from a teleological process into a 'substantial and hard-won achievement'. In a print culture where piratical practices were rife, those involved in producing the Philosophical Transactions had to discipline both printers and readers if they were to make it an authoritative vehicle of natural knowledge. Moreover, the process was both fragile and subject to reverses.

Compared with the literature on the fabrication of scientific publications, little attention has been paid to the use of such publications by their readers and owners. Faced with the question of what contemporaries did with particular scientific books, many historians still rely largely on their sense of the author's intended readership (whether derived from the author's explicit statements or from textual criticism), supplemented by a handful of reviews and occasionally by recorded comments of individual readers. Yet, as recent

3 B. Lightman, “"The voices of nature”: popularizing Victorian science', in B. Lightman (ed.), Victorian Science and Culture, Chicago and London, 1997, 187-211, 188. 
literature in the history of the book demonstrates, a more sophisticated and satisfactory history of reading practices and book-collecting is possible. ${ }^{4}$ The evidence may sometimes be diffuse and is certainly diverse, ranging from information about the distribution of reading matter, through private records of reading, to published advice about reading and representations of reading - both visual and literary. Yet it is surprisingly abundant and can contribute significantly to a cultural history of science.

Exploring in detail the historical encounters of readers with printed matter enables the historian to elaborate an account of scientific communication by print which, instead of methodologically privileging the role of scientific authors, acknowledges the complex and contested nature of such communication. The place of natural knowledge in culture cannot be understood simply from the communicative acts of scientific popularizers; as Jim Secord observes, it must begin 'from the ground up, looking at the basic material products of cultural life'. ${ }^{5}$ As material products, books, newspapers, magazines, almanacs and broadsides have been of great importance, standing alongside such apparently contrasting objects as gas-lamps, menageries and steam-engines. The newly felt imperative to investigate other material objects should alert us to the need to explore printed matter in a new way.

4 See, for instance, W. H. Sherman, John Dee: The Politics of Reading and Writing in the English Renaissance, Amherst, 1995; A. Johns, 'The physiology of reading in Restoration England', in J. Raven, H. Small and N. Tadmor (eds.), The Practice and Representation of Reading in England, Cambridge, 1996, 138-61; and A. N. Walters, 'Conversation pieces: science and politeness in eighteenth-century England', History of Science (1997), 35, 121-54.

5 J. Secord, 'Evolution for the people' (discussion paper); quoted in R. Cooter and S. Pumfrey, 'Separate spheres and public places: reflections on the history of science popularization and science in popular culture', History of Science (1994), 32, 237-67, 243. See also idem, Victorian Sensation: The Extraordinary Publication, Reception and Secret Authorship of Vestiges of the Natural History of Creation, Chicago, forthcoming. 